\title{
Effectiveness of Blood Learning Based on the Ethnochemical Approach Module on Improving Science Literation Abilities
}

\author{
Seprianto ${ }^{1}$, Molani Paulina Hasibuan ${ }^{2}$ \\ Department of Chemical Education, Faculty of Teacher Training and Education, Universitas Samudra, Indonesia \\ seprianto_kimia@unsam.ac.id
}

\begin{abstract}
The purpose of this study was to determine the effectiveness of module-based online learning with an ethnochemical approach in improving students' scientific literacy skills. This research is a quasi-experimental study with a pretest-posttest nonequivalent control group design. The study population was students of the Faculty of Teacher Training and Education, Samudra University who were taking basic chemistry courses. The results showed an increase in science literacy skills based on the $N$-gain value in the experimental class of 0.54 in the medium category and 0.33 in the control class who were also in the medium category. Analysis with $t$ test based on the posttest value obtained sig. (2-tailed) 0.030 or $<0.05$, which indicates a significant difference in the posttest scores of the two classes. Based on these two Kés, it can be concluded that module-based online learning with an ethnochemical approach is effective for improving students' scientific literacy skills. The results showed an increase in science literacy skills based on the $N$-gain value in the experimental class of 0.54 in the medium category and 0.33 in the control class who were also in the medium category. Analysis with t test based on the posttest value obtained sig. (2-tailed) 0.030 or $<0.05$, which indicates a significant difference in the posttest scores of the two classes. Based on these two Kés, it can be concluded that modulebased online learning with an ethnochemical approach is effective for improving students' scientific literacy skills. The results showed an increase in science literacy skills based on the $N$-gain value in the experimental class of 0.54 in the medium category and 0.33 in the control class who were also in the medium category. Analysis with $t$ test based on the posttest value obtained sig. (2-tailed) 0.030 or $<0.05$, which indicates a significant difference in the posttest scores of the two classes. Based on these two Kés, it can be concluded that module-based online learning with an ethnochemical approach is effective for improving students' scientific literacy skills.
\end{abstract}

Keywords

online learning, module; ethnochemistry, scientific literacy

\section{Introduction}

In the era of globalization, the world is experiencing rapid changes in all areas of life. This change needs to be anticipated by mastering 21st century skills (Redhana, 2019). One of the skills needed to survive in the era of globalization is scientific literacy.Science literacy namely ability to engage with science-related issues and with scientific ideas, as a reflective citizen (OECD, 2019a). The 2018 PISA results show that the scientific literacy of students in Indonesia is ranked 70th out of 78 participating countries with an average score of 396 (OECD, 2019b). Meanwhile, abilityscientific literacy of education students in Indonesia is known to be low(Sujana, et al., 2014), including chemistry education students in Aceh (Seprianto, et al., 2017). 
The rapid development in information technology has made the flow of information exchange faster. The process of globalization and cross-cultural interactions between ethnic groups in Indonesia creates different cultural identities and loses their original cultural identities (Rahmawati, et al., 2017). In identity, there is no ethnic group that can maintain an identity that can be believed without signs, symbols, which underlies the values that show a clear identity, however the signs and symbols are the result of interaction with the group - other groups and comprehensive signs of ethnic values and development as such to bring out a positive image to transcend boundaries (Suharyanto and Hidayat, 2018). One form of cultural identity that ethnic groups in Indonesia have is ethnochemistry. Ethnochemistry is a certain cultural behavior in a community group that is chemically related (Rosa \& Orey, 2011). Initial research shows that there are several ethnochemicals that are owned by the Acehnese ethnicity in eastern Aceh, such as the use of natural materials as medicines, food additives, cleaners, and others (Seprianto \& Jofrishal, 2019). Ethnochemistry can be integrated in learning.

Every society has several concepts that are supernatural, spirits, gods or impersonal forces that are different from the others and in some meanings are superior to other forces that are used by humans as regulators of natural events and nature. And its activity is somehow capable of giving meaning to aspects of unusual human experience such as a phenomenon which makes logic unreasonable. In this case humans need religion which then gives birth to culture or vice versa is also a religious culture (Angkat et al, 2019). Organizational culture is a set of assumptions or systems of beliefs, values, and norms developed in organizations that serve as guidelines for behavior for its members to overcome the problem of external and internal adaptation. Organizational culture is a pattern of beliefs and organizational values that are believed and imbued by all members in doing work as an appropriate way to understand, think, and feel about related problems, so that it will become a value or rule within the organization (Sihombing et al, 2020). Furthermore, to meet the interactional needs in the learning process the teacher must know and understand the character education development procedures that are neatly arranged in the semester learning plan. So that in its application and inculcation of character values it will be easy to read with the cognitive psychomotor and affective aspects that have indicators of assessment (Perdana, 2020).

Advances in information and communication technology in the era of the digital revolution have been used as a learning delivery strategy, such as through online learning (Kirna, 2014). In learning that combines face-to-face learning and online learning, it is possible for students to develop 21st century skills (Redhana, 2019). Online learning can use multiple platforms such as Google Classroom, Edmodo, and others. Therefore, it is necessary to do a studyto determine the effectiveness of module-based online learning with an ethnochemical approach to improving students' scientific literacy skills. If the effectiveness is high, then this study can be recommended as a way to increase the science literacy score in Indonesia. The urgency of this research includes: Online learning is increasingly needed in the era of the digital revolution, starting from the loss of ethnochemistry which is the local wisdom of ethnic groups in Indonesia, and national targets in education to increase the scientific literacy score of Indonesian students. 


\section{Research Methods}

This research is a quasi-experimental research using the pretest-posttest nonequivalent control group design. The study population was the students of the Faculty of Teacher Training and Education at Samudra University who were taking basic chemistry courses. Sampling using purposive sampling technique. The experimental group is a class with module-based online learning with an ethnochemical approach with a sample size of 10 students, while the control group is a class with non-module based online learning with an ethnochemical approach with a sample size of 10 students.

Table 1. Research design

\begin{tabular}{llll}
\hline Group & Pretest & Treatment & Posttest \\
\hline Experiment & $\mathrm{Y} 1$ & $\mathrm{Xa}$ & $\mathrm{Y} 2$ \\
Control & $\mathrm{Y} 1$ & $\mathrm{Xb}$ & $\mathrm{Y} 2$ \\
\hline
\end{tabular}

Information:

Y1 $=$ Pretest of scientific literacy skills

$\mathrm{Xa}=$ online learning based on ethnochemistry module

$\mathrm{Xb}=$ online learning is not based on ethnochemical module

$\mathrm{Y} 2=$ Posttest science literacy skills

The data of this research are in the form of pretest and posttest scores of students' scientific literacy abilities. Students' scientific literacy abilities were measured using a scientific literacy test instrument. The increase in students' scientific literacy was analyzed based on the $\mathrm{N}$-gain, using the formula:

$\mathrm{g}=\frac{\text { Skor posttest }- \text { Skor pretest }}{\text { Skor maksimal }- \text { Skor pretest }}$

With the gain score analysis criteria: $\mathrm{g} \geq 0.7$ high category, $0.3 \leq \mathrm{g}<0.7$ medium category, and g <0.3 category low (Hake, 1998). The difference in the increase in scientific literacy between the experimental class and the control class was tested for differences using the t-test in the SPSS program.

\section{Results and Discussion}

The average scores of students' scientific literacy skills are presented in Table 2. From Table 2, it can be seen that there is an increase in scientific literacy skills in both the control and experimental classes. Based on the average pretest score, the initial scientific literacy abilities of the two classes are relatively the same. However, the posttest average and $\mathrm{N}$-gain of the experimental class were better than the control class because the experimental class got online learning with the help of modules that emphasize ethnochemistry or chemistry inlocal culture. This is in line with the research of Nisa ', et al. (2016) who show that the average scientific literacy ability increases with the use of ethnoscience integrated modules.

The $\mathrm{N}$-gain for both classes is 0.54 for the experimental class and 0.33 for the control class. The increase in scientific literacy skills in the experimental class and control class is classified as moderate based on Hake's (1998) criteria. However, a higher N-gain in the experimental class indicated an increase in scientific literacy skills with the application of online learning using ethnochemical based modules. Afrianawati, et al. (2016), stated that 
the ethnoscience-based learning model links learning in the classroom with what students encounter in everyday life and encourages active participation of students in the learning process.

Table 2. The average pretest, posttest, and N-gain scores in the experimental class and control class

\begin{tabular}{clcccc}
\hline No. & Class & Pretest & Posttest & N-gain & Category \\
\hline 1. & Control & 51 & 68 & 0.33 & Moderate \\
2. & Experiment & 50 & 79 & 0.54 & Moderate \\
\hline
\end{tabular}

Testingnormality and homogeneity were carried out to meet the requirements of the t-test. The results of the data normality test are presented in Table 2. Normality testing uses the Shapiro-Wilk method because of the relatively small number of samples. From Table 3 , it can be seen that the significance in the experimental class and control class is $>0.05$, so it can be concluded that the data in the two classes are normally distributed. Test resultsThe homogeneity of the two classes is presented in Table 4. From Table 4, the significance obtained is $>0.05$, which means that the two classes have the same or homogeneous variance.

Table 3. The results of the normality test for the experimental class and the control class

\begin{tabular}{clccc}
\hline No. & \multicolumn{1}{c}{ Class } & df & Sig. & Interpretation \\
\hline 1. & Control & 10 & 0.412 & Normal \\
2. & Experiment & 10 & 0.569 & Normal \\
\hline
\end{tabular}

Table 4. Homogeneity test results for both classes

\begin{tabular}{ccccc}
\hline Class & df1 & df2 & Sig. & Interpretation \\
\hline Control and Experiment & 1 & 18 & 0.442 & Homogeneous \\
\hline
\end{tabular}

The t-test was used to determine differencesscientific literacy skills in the experimental class and the control class. The t-test was performed on the posttest and ngain data. The results of the t-test on the posttest data are presented in Table 5, while the results of the t-test for the $\mathrm{N}$-gain data are presented in Table 6 . Table 5 shows the sig. (2tailed) $<0.05$. These results indicate a significant difference in the scientific literacy abilities of the two classes after being given treatment. Meanwhile, Table 6 also shows sig. (2-tailed) $<0.05$, which means that the increase in scientific literacy skills in the two classes is significantly different. These results indicate that module-based online learning with an ethnochemical approach has an effect on improving scientific literacy skills.

Table 5. The t-test results of the posttest data of the experimental class and the control class

\begin{tabular}{ccccc}
\hline Data & $\mathrm{t}$ & $\mathrm{df}$ & Sig. (2-tailed) & Interpretation \\
\hline Posttest & 2,356 & 18 & 0.030 & $\begin{array}{c}\text { There are } \\
\text { significant } \\
\text { differences }\end{array}$ \\
\hline
\end{tabular}

Table 6. The results of the t-test for the N-gain data of the experimental class and control class

\begin{tabular}{ccccc}
\hline Data & $\mathrm{t}$ & $\mathrm{df}$ & Sig. (2-tailed) & Interpretation \\
\hline N-gain & 2,198 & 18 & 0.041 & $\begin{array}{c}\text { There are } \\
\text { significant } \\
\text { differences }\end{array}$ \\
\hline
\end{tabular}


The results of the analysis of the average posttest, n-Gain and t-test results show that online learning based on modules with an ethnochemical approach is effective for improving scientific literacy skills. This is in line with the research of Setiawan, et al. (2017) which shows that the use of science modules based on local wisdom can improve students' scientific literacy skills both theoretically and empirically. Like modules, worksheets with ethnoscience are also effective in improving students' scientific literacy skills (Ariningtyas, et al., 2017). The application of ethnoscience-filled learning can be used to improve students' scientific literacy skills (Perwitasari, et al., 2016). In addition to improving scientific literacy skills, implementing modules and learning with an ethnochemical approach can also improve learning outcomes and learning effectiveness (Rosa \& Orey, 2011; Ajayi, et al., 2017).

\section{Conclusion}

The results showed an increase in scientific literacy skills based on $\mathrm{N}$-gain in the experimental class of 0.54 which is in the medium category and in the control class of 0.33 which is also in the moderate category. Analysis with t test based on the posttest value and $\mathrm{N}$-gain obtained sig. (2-tailed) $<0.05$ which indicates a significant difference in the posttest and $\mathrm{N}$-gain scores of the two classes. Based on these two analyzes, it can be concluded that online learning based on modules with an ethnochemical approach is effective for improving students' scientific literacy skills.

\section{Acknowledgement}

Thanks are conveyed to the Ocean University Research Institute, Community Service and Quality Assurance (LPPM-PM) through research funding for the Leading Basic Research (PDU) scheme in 2020.

\section{References}

Angkat, M., et al. (2019). Construction of Religious Identity in Pakpak Culture Community in Dairi District. Budapest International Research and Critics InstituteJournal (BIRCI-Journal). P. 487-494.

Ajayi, OV, Achor, EE, \& Og, P. 2017. Use of ethnochemistry teaching approach and achievement and retention of senior secondary students in standard mixture separation techniques. International Center for Science, Humanities and Education Research Journal, 3 (1): 21-30.

Arfianawati, S., Sudarmin, \& Sumarni, W. 2016.Ethnoscience-based chemistry learning model to improve students' critical thinking skills. Journal of Mathematics and Natural Sciences Teaching, 21 (1): 46-51.

Ariningtyas, A., Wardani, S., \& Mahatmanti, W. 2017. The effectiveness of student worksheets containing ethnoscience on salt hydrolysis material to improve scientific literacy of high school students. Journal of Innovative Science Education, 6 (2): 186196.

Hake, RR 1998. Interactive-engagement versus traditional methods: A six-thousandstudent survey of mechanics test data for introductory physics courses. American Journal of Physics, 66 (1): 64-74.

Nisa ', A. Sudarmin, \& Samini. 2015. The effectiveness of using ethnoscience integrated modules in problem-based learning to improve students' scientific literacy. Unnes Science Education Journal, 4 (3): 1049-1056. 
Kirna, IM 2014. Development of online content to support blended learning in Basic Quantum Chemistry courses. Educational Horizons, 33 (2): 186-197.

OECD. 2019a. PISA 2018 Assessment and analytical framework, PISA, OECD Publishing, Paris, https://doi.org/10.1787/b25efab8-en.

OECD. 2019b.PISA 2018: insights and interpretations, PISA, OECD Publishing, Paris, https://www.oecd.org/pisa/PISA\%202018\%20Insights\%20and\%20Interpretations\%2 0FINAL\%20PDF.pdf.

Perdana, D.A., et al. (2020). Nasionalism: Character Education Orientation in Learning Development. Budapest International Research and Critics Institute-Journal (BIRCIJournal). P. 4026-4034.

Perwitasari, T., Sudarmin, \& Linuwih, S. 2016. Increasing scientific literacy through learning energy and its changes contains ethnoscience in smoking fish. Journal of Science Education Research, 1 (2): 62-70.

Rahmawati, Y., Ridwan, A., \& Nurbaity. 2017. Should we learn culture in chemistry classroom? Integration of ethnochemistry in culturally responsive teaching. AIP Conference Proceeding 1868, 030009, (online), https://doi.org/10.1063/1.4995108.

Redhana, IW 2019. Developing 21st century skills in chemistry learning. Journal of Chemical Education Innovation, 13 (1): 2239-2253.

Rosa, M. \& Orey., DC 2011. Ethnomathematics: the cultural aspects of mathematics. Revista Latinoamericana de Etnomatematica, 4 (2): 32-54.

Sihombing, T.P., et al. (2020). The Effect of Accounting Information and Organizational Culture on Decision Making. Budapest International Research and Critics InstituteJournal (BIRCI-Journal). P. 522-530.

Sujana, A., Permanasari, A., Sopandi, W., \& Mudzakir, A. 2014. Literasi kimia mahasiswa PGSD dan guru IPA sekolah dasar. Jurnal Pendidikan IPA Indonesia, 3(1): 5-11.

Seprianto \& Jofrishal. 2019. Knowledge inventory of ethnochemistry based on Aceh local wisdom for chemical lecture development. Jurnal Pengajaran MIPA, 22(2).

Seprianto, Jofrishal, \& Mauliza. 2017.Pre service chemistry teachers scientific literacy based on PISA and TIMSS results for international and indonesian students. Jurnal Pengajaran MIPA, 22(2): 151-157.

Setiawan, B., Innatesari, D.K., Sabtiawan, W.B., \& Sudarmin. 2017. The development of local wisdom-based natural science module to improve science literation of students. Jurnal Pendidikan IPA Indonesia, 6(1): 49-54.

Suharyanto, A., and Hidayat, T.W. (2018). Revealing Medan's Chinese Ethnic Identity in Advertising Grief at Harian Analisa Newspaper. Budapest International Research and Critics Institute-Journal (BIRCI-Journal). P. 83-92. 